\title{
The Impacts of Team Listening and Unscheduled Meetings on Team Coordination
}

\author{
Peter W. Cardon, Bryan Marshall
}

Received: October 29, $2014 \quad$ Accepted: November 17, $2014 \quad$ Available online: November 28, 2014
doi:10.11114/smc.v2i2.570
URL: http://dx.doi.org/10.11114/smc.v2i2.570

\begin{abstract}
We examined the impacts of the team listening environment and the frequency of team communication on team coordination in business environments. While there is a long history of examining listening on an individual and interpersonal level in communication research, the construct of a Team Listening Environment (TLE) was only recently developed. We surveyed 233 full-time working professionals, including executives, mid-level managers, and entry-level managers. Using multiple regression analysis, we found that a team listening environment is the single most important contributor to team coordination. We also found that the frequency of unscheduled meetings increased team coordination but that the frequency of scheduled meetings did not increase team coordination. Other factors such as length of employment with current employer, frequency of other forms of communication, age, and gender did not impact team coordination.
\end{abstract}

Keywords: team listening, listening, unscheduled meetings, team coordination, media selection, media richness

\section{Introduction}

Listening is often considered among the most important communication skills for business leaders and managers. In one recent survey of 7,674 MBA alumni from around the world, listening was identified as the second most important communication skill on a survey of 16 communication competencies (ability to work with others was ranked slightly higher). Listening ranked above the ability to influence others, communicating with diplomacy and tact, managing expectations, leadership skills, understanding problems from diverse perspectives, presentation skills, networking skills, writing skills, meeting management, negotiation skills, managing organizational politics, giving constructive feedback, cross-cultural sensitivity, and mentoring skills (GMAC, 2010). Yet, research about listening has focused primarily on interpersonal communication, not team communication. Until recently, no listening assessment had been developed to examine the listening environment for teams (Johnston, Reed, and Lawrence, 2011). Therefore, little is known about how much a positive team listening environment impacts team performance.

Most teams meet often to coordinate their activities lately. The impacts of good meetings can be long-lived - one recent study showed that good meetings were correlated to organizational success as far as 2-1/2 years after the meeting (Kauffeld \& Lehmann-Willenbrock, 2012). Yet, even with all of the research about teamwork and team performance, relatively little is known about how the frequency of various types of meetings leads to effective team coordination. In particular, little is known about how the frequency of major types of team communication-including scheduled face-to-face (F2F) meetings, unscheduled F2F meetings, phone calls, and emails-impacts team coordination. In this study, we examined the degree to which a quality team listening environment and the frequency of various types of meetings and communications contributed to team coordination. We also took into account factors such employment tenure, age, and gender.

\section{Literature Review}

Management and communication books abound with advice about listening and meeting often. Yet, little research is available about the role that a quality team listening environment has on team coordination. Furthermore, management and communication books abound with advice about meeting often in teams to improve team coordination. Yet, little research examines how the frequency of communicating via various communication channels improves team coordination.

In our study, we specifically address the nature of team communication and team coordination. A variety of factors in recent years are driving an increasing amount of professional communication to teams rather than through hierarchical command approaches. Organizations are increasingly run under the assumption that effective teamwork and 
collaboration drive innovation, higher productivity, and higher employee satisfaction (Berry, 2006, 2011; Costa, 2003; Costa \& Anderson, 2011; Costa \& Peiró, 2009; Costa, Roe, \& Taillieu, 2001; Douglas, Martin, \& Krapels, 2006; Lawler $\&$ Finegold, 2000). In this review of literature, we focus on two aspects of team communication: listening environment and frequency of team communication.

\subsection{Listening and Related Impacts on Workplace Performance}

Listening has long been associated with better business performance. One prominent model of effective listening breaks it into six components: hearing, understanding, interpreting, evaluating, remembering, and responding (Brownell, 1990). In particular, effective listening is correlated with the following measures of organizational performance: better sales performance; more satisfied and committed customers; higher product and service quality; higher productivity; more effective change management; lower employee absenteeism; lower employee turnover; higher employee motivation; and team development and learning. It is correlated with the following measures of business and workplace relationships: higher perceived trustworthiness; higher perceptions of supportiveness; higher organizational commitment; higher interpersonal influence; lower stress among subordinates; and managerial and leadership success (Ames, Maissen, \& Brockner; Brunner, 2008; Comer \& Drollinger, 1999; Flynn, Valikoski, \& Grau, 2008; Goby \& Lewis, 2000; Haas \& Arnold, 1995; Henderson, 2008; Kluger \& Zaidel, 2013; Mineyama et al., 2007; Ramsey \& Sohi, 1997; Stine, Thompson, \& Cusella, 1995).

In response to the need to develop listening skills, many training and pedagogical approaches have been developed (Cooper, 1997; Hoppe, Drath, Ernst, \& McCauley, 2006; Johnson, Pearce, Tuten, \& Sinclair, 2003). Yet, on the whole, these approaches have not been prioritized in most business communication curricula. Furthermore, most poor listeners are unaware of the severity of their skill gaps. For example, one of the more extensive studies of its kind showed that poor-listening managers are not aware they're poor listeners. In the study, 144 managers self-evaluated their listening performance and 827 of their subordinates evaluated the listening performance of these same managers. Of the poor-listening managers (bottom 25 percentile), 6 percent thought they were excellent listeners, 88 percent thought they were good listeners, and 6 percent thought they were fair listeners. None thought they were poor or very poor (Brownell, 1990).

Yet, until a few years ago, no listening assessments had been developed with a focus on the team environment. Rather, listening scales had focused on the individual listening performance in interpersonal interactions (i.e., Barker, Pearce, \& Johnson, 1992; Cooper \& Buchanan, 2003; Mickelson \& Welch, 2013; Pearce, Johnson, \& Barker, 2003; Watson, Barker, \& Weaver, 1995). To fill this void, Johnston, Reed, and Lawrence (2011) developed the team listening environment (TLE) instrument to assess listening at a team level. In this study, we examine the impact of the team listening environment on team coordination. This is the first known study to examine this key indicator of team performance.

\subsection{Frequency of Meetings and Related Impacts on Team Coordination}

Research has overwhelmingly suggested the key role that communication holds in facilitating team coordination (Dyer, Dyer, \& Dyer, 2013; Mathieu, Maynard, Rapp, \& Gilson, 2008; Marks, Mathieu, \& Zaccaro, 2001; Tesluk \& Mathieu, 1999). However, although teamwork and team performance have been examined thousands of times in the scholarly literature, relatively scant research exists about the frequency of meetings on team coordination (Kauffeld \& Lehmann-Willenbrock, 2012). Of studies that have focused on the impacts of the frequency of meetings on team coordination, nearly all have focused on formal, scheduled meetings (Kauffeld \& Lehmann-Willenbrock, 2012; Rogelberg et al., 2006). In this section, we describe research that has focused on the frequency of various media for team communication. We frame the conversation around unscheduled meetings because no known studies have focused on the how frequency of unscheduled meetings impacts team coordination.

The inattention to the impacts of unscheduled meetings is a glaring hole in empirical research for several reasons. First, manager time-use studies, primarily conducted during the 1970s, 80s, and 90s, showed the major role of unscheduled meetings in the workplace. Second, media richness theory suggests that teams would coordinate more effectively through the rich communication facilitated in unscheduled meetings. Third, abundant scholarly management advice specifically promotes spontaneity in meetings.

Beginning in the late early 1970s, management scholars began examining the time use of managers. These studies showed that managers engaged in scheduled and unscheduled F2F meetings. In the first major study of its kind, Mintzberg (1971) found that managers held eight meetings per day, half of which were unscheduled. Many management studies of the 1970s, 80s, and 90s were replications of this seminal study. Oshagbemi (1995) reviewed 64 studies of managers' time use between 1981 and 1993. He found that managers spent between 32 and 69 percent of their time on meetings. Of studies that segmented between scheduled and unscheduled meetings, they generally showed more time is spent on scheduled meetings but more unscheduled meetings occur. In Panko's (1992) meta-analysis of more than 50 
time-use studies, he found that scheduled meetings constituted 41 percent of managers' F2F communication and unscheduled meetings constituted 53 percent of managers' F2F communication. Few of these studies examined differences by gender. One exception was that of MacLeod, Scriven, and Wayne (1992), which found that female managers spent more time in unscheduled meetings than male managers. Women spent 46.2 percent of their time in unscheduled meetings and 30.6 percent in scheduled meetings compared to 40.8 percent in unscheduled meetings and 40.5 percent in scheduled meetings among men. Most time-use studies of managers have been largely descriptive, without attempting to demonstrate the effectiveness of various managerial communications. One exception is the work of Martinko and Gardner (1990), which did not find a link between the overall time invested in communication activities and team performance.

Surprisingly, although so many time-use studies had been conducted of managers, few such studies had been conducted in the context of teams. One of the first studies to do so was Kraut and colleagues (1990) examination of informal communication within teams. They concluded that those team communications in the workplace that are unscheduled are comparatively rich and open because they do not have an arranged agenda. They studied 117 conversations at R\&D organizations and characterized $12 \%$ of the conversations as scheduled and $88 \%$ as unscheduled or informal. Although the vast majority of meetings were informal, the informal meetings collectively accounted for just $1 / 3$ as much time as formal, scheduled meetings. They found that the unscheduled meetings were integral to coordinating and executing projects and characterized these unscheduled meetings as "just-in-time consultations" (p. 22). They also found that these unscheduled meetings were critical for improving the social cohesiveness of teams. Several more recent studies examining the time use of team communication activities have shown that the four most common communication channels are scheduled meetings, unscheduled meetings, email, and phone conversations (Arora, Gonzalez, \& Payne, 2011; Haythornthwaite, 2005; Haythornthwaite, Wellman, \& Mantei, 1994).

Media richness theory posits that task performance improves when communication media are richer. Characteristics that make media richer include access to verbal and nonverbal cues, use of natural language, immediate feedback, and expression of feelings and emotions. Generally, the order of richness has been identified as face-to-face (F2F) communication, videoconferencing, telephone, chat, email, and print (Daft \& Lengel, 1986; Webster \& Hackley, 1997). Generally, research suggests that richer channels, particularly F2F communication, leads to higher group effectiveness and reduced time needed to complete tasks (Baltes et al., 2002).

However, of the literally thousands of studies that focus on teamwork and team coordination, only a few have directly examined the impact that the frequency of using various communication channels had on team coordination (Kauffeld \& Lehmann-Willenbrock, 2012). In some cases, these studies do not support the notion that richer communication facilitates more team coordination. For example, Fussel and colleagues (1998) examined 50 teams (277 team members altogether) and found that increased email use significantly and positively impacted team coordination, whereas F2F communication did not. Kraut and colleagues (2005) found that the frequency of communication and the history working together did not impact team coordination.

Most studies of communication media have focused on pairings of F2F versus one other form of less rich media (Leondardi, Neeley, \& Gerber, 2012; Staples \& Webster, 2003). One exception compared team communication via three media: F2F meetings, videoconferencing, and text-based chat. It showed that team performance was better in F2F meetings and videoconferencing than text-based chat (Hambley, O'Neill, \& Kline, 2007). Yet, studies such as this are perplexing because other studies suggest otherwise. For example, McDonough (1999) examined the use of phone calls and videoconferencing on the performance of global product development teams. They found that the use of videoconferencing was negatively related to performance.

In these tests of media richness in the context of team coordination, however, comparisons have not focused between various types of rich, F2F communication. In particular, these studies have not examined scheduled versus unscheduled F2F meetings. One known study of team communication did address the nature of unscheduled versus scheduled phone calls. Maltz (2003) examined communication between teams of marketing managers and non-marketing managers. They found that unscheduled phone calls had less positive impacts than scheduled phone calls on perceived information quality.

Finally, the empirical inattention to unscheduled meetings in fostering team coordination is surprising given the common management advice of managing by walking around (MBWA), which implies the benefits of spontaneous, unscheduled interactions (Peters and Waterman, 1982). Many scholars suggest that informal, unscheduled conversations and meetings lead to better management, higher team performance, and higher trust (Behn, 1988 Handy, 1995). These various management thinkers suggest that in unscheduled meetings, communication is more informal, rich, and valuable. In a similar vein, over five decades theoretical pieces about organizational communication climate have identified spontaneity as leading to a supportive communication climate, whereas strategy as leading to a defensive 
communication climate (Baker, 1980; Beck, \& Beck, 1986; Gibb, 1961; Ireland, Van Auken, \& Lewis, 1978). Regarding the spontaneity-strategy divide, Ireland, Van Auken, and Lewis (1978) stated the following over 35 years ago: The enactment of spontaneous communication actions, within certain tolerance limits, serves as a backdrop to the transmission of honest and frequently desirable messages from one organizational member to another. Such communication spontaneity would probably not be observable within a defensive climate, as employees would feel that most organizational messages are transmitted as a part of a strategy designed to control their actions. Accordingly, these employees will be hesitant to communicate with others until they have determined the personalized, strategic effect of such messages (p. 6).

Furthermore, many scholarly case studies use a similar logic to highlight how collaborative companies rely on spontaneous, flexible, and, by implication, unscheduled team communications (Adler, Heckscher, \& Prusak, 2011; Gratton \& Erickson, 2007). Yet, we're unaware of any empirical research that pinpoints the degree to which the frequency of unscheduled meetings contributes to team coordination.

Overall, the literature on frequency of meetings and team coordination is quite limited. In particular, there are no direct comparisons between the most common forms of team communication (scheduled meetings, unscheduled meetings, phone calls, and email) (Arora, Gonzalez, \& Payne, 2011; Haythornthwaite, 2005; Haythornthwaite, Wellman, \& Mantei, 1994) and their impacts on team coordination. Furthermore, although time-use studies, media richness theory, and scholarly management advice imply the value of spontaneous and unscheduled meetings, no known empirical research exists to support the claim that the frequency of unscheduled meetings improves team coordination.

\section{Method}

With our survey, we intended to identify the following: (a) the degree to which team listening environment impacts team coordination; (b) the degree to which the four most common forms of team communication (scheduled meetings, unscheduled meetings, phone calls, and email) impact team coordination; and (c) the degree to which gender, age, and tenure with company impact team coordination.

We relied on two scales for the survey. First, we assessed team coordination with Jarvenpaa and Leidner's (1999) revised version of Taylor and Bower's (1972) scale. In our survey, this measure showed high reliability with a Cronbach's alpha of .911. For the team listening scale, we used Johnston, Reed, and Lawrence's (2011) team listening environment (TLE) scale. This measure also showed high reliability, with a Cronbach's alpha of .946.

We examined the following four communication channels for team communication: scheduled meetings, unscheduled meetings, phone calls, and email. We chose these communication channels because they have been identified as the most commonly used communication channels for team communication in a variety of studies extending over several decades (Arora, Gonzalez, \& Payne, 2011; Haythornthwaite, 2005; Haythornthwaite, Wellman, \& Mantei, 1994).The scale used for frequency of team communication ranged from 1 , hourly, to 7 , never $(1=$ hourly; $2=$ several times per day; 3 = daily; $4=$ a few times per week; $5=$ weekly; $6=$ rarely; $7=$ never).

We also included items on the survey for gender, age, and tenure with the company. Some research has suggested that women are more likely to use unscheduled meetings (MacLeod, Scriven, and Wayne) and people who have worked longer at a company are able to coordinate more efficiently (Katz, 1982; Katz \& Tushman, 1979; Kraut et al., 2005).

The survey was administered online. Our survey sample consisted of alumni from the business school of one of our institutions. We had a list of email addresses from approximately six hundred former business students. Ultimately, we received 231 complete, usable surveys, yielding a response rate of approximately 38 percent. The breakdown of current professions roughly matches the percentage of enrollments in various degrees at the selected institution. We do note that the institution has had an emphasis on general business administration degrees. Given the broad representation across age groups, we view the sample as likely representative of many American business environments. In Table 1, we provide descriptive statistics for our sample. 
Table 1. Characteristics of Survey Sample

\begin{tabular}{lll}
\hline & $\mathrm{n}$ & $\%$ \\
\hline Gender & & 54.5 \\
Men & 126 & 45.5 \\
Women & 105 & 21.2 \\
21 to 25 & 49 & 10.4 \\
26 to 30 & 24 & 21.6 \\
31 to 40 & 50 & 22.9 \\
41 to 50 & 53 & 22.1 \\
51 to 65 & 51 & 1.7 \\
Over 65 & 4 & 7.4 \\
Accounting & 17 & 6.1 \\
Finance & 14 & 2.2 \\
Human Resources & 5 & 16.9 \\
Information Systems & 39 & 17.7 \\
Management & 41 & 6.5 \\
Marketing & 15 & 4.3 \\
Supply Chain/Operations & 10 & 39.0 \\
Other & 90 & 100 \\
Total & 231 & \\
\hline
\end{tabular}

\section{Results}

In this section, we first show descriptive statistics for the TLE and team coordination scales. Then, we discuss the impact of a team listening environment on team coordination. Overall, we found that roughly three-quarters (72.7 to 79.2 percent) of professionals in our survey agreed with various items in the team listening environment scale (see Table 2).

Table 2. Descriptive Statistics for the Team Listening Environment Scale

\begin{tabular}{llll}
\hline Item & M & S.D. & $\%$ Agree \\
\hline The other group members genuinely want to hear my point of view. & 3.91 & .88 & $73.8 \%$ \\
The other group members show me that they understood what I say. & 3.93 & .85 & $73.6 \%$ \\
The other group members listen to what I say. & 4.02 & .83 & $79.2 \%$ \\
The other group members understood me. & 3.93 & .87 & $72.7 \%$ \\
The other group members seem attentive to what others have to say. & 3.87 & .88 & $72.7 \%$ \\
The other group members pay attention to me. & 4.01 & .84 & $75.8 \%$ \\
Total & 23.73 & 4.49 & \\
\hline
\end{tabular}

Note. Percentage agree refers to those who selected agree (4) or strongly agree (5) on the survey.

We found more variation in agreement among the items in the team coordination scale. Whereas approximately 81 percent of professionals agreed that their work groups were dedicated to meeting objectives successfully, just 61 percent agreed that everyone in their work groups understood what to do and how to do it (see Table 3).

Table 3. Descriptive Statistics for the Team Coordination Scale.

\begin{tabular}{llll}
\hline Item & M & S.D. & $\%$ Agree \\
\hline Members in my work group plan together and coordinate efforts effectively. & 3.87 & .94 & $72.7 \%$ \\
Everyone in my work group understands what to do and how to do it. & 3.66 & .88 & $61.0 \%$ \\
As a work group, we are dedicated to meeting our objectives successfully. & 4.10 & .89 & $80.5 \%$ \\
Group members work hard to provide substantive and timely feedback on ideas & 3.82 & .94 & $67.1 \%$ \\
$\quad$ and work presented. & 4.00 & .89 & $76.2 \%$ \\
My work group is usually aware of important events and situations. & $69.3 \%$ \\
The people in my work group make my job easier by sharing their ideas and & 3.88 & 1.00 & \\
$\quad$ opinions with me. & & & \\
$\quad$ Total & 23.35 & 4.62 & \\
\hline
\end{tabular}

Note. Percentage agree refers to those who selected agree (4) or strongly agree (5) on the survey.

Our primary interest was examining how a team listening environment contributes to team coordination. We ran a regression analysis with team coordination as the dependent variable. In addition to team listening, we also included age, gender, employment tenure, and communication frequency in our analysis. In terms of communication frequency, we included unscheduled (unscheduled) meetings, scheduled meetings, email, and phone calls.

Team listening environment significantly and positively $(\mathrm{p}<.000)$ impacted team coordination. In fact, it was the single 
strongest contributor to team coordination. Of the other variables, only one item was also a significant contributor to team coordination: unscheduled meetings $(\mathrm{p}<\mathrm{.045}$ ). Age, gender, employment tenure, and frequency of other communication channels (scheduled meetings, email, and phone) had no impact on team coordination.

Table 4. Regression of Team Coordination

\begin{tabular}{llll}
\hline & $B$ & $S E B$ & .471 \\
\hline Age & .016 & .022 & \\
Gender (Men) & & & .189 \\
Women & .672 & .510 & .302 \\
Employment Tenure & -.215 & .208 & $.000^{* *}$ \\
Team Listening Environment & .600 & .056 & $.045^{*}$ \\
Unscheduled Meetings & .377 & .187 & .473 \\
Scheduled Meetings & -.146 & .203 & .996 \\
Email & .001 & .190 & .112 \\
Phone & -.306 & .192 & \\
\hline
\end{tabular}

Note. $R^{2}=.35 . * p<.05 . * * p<.01$. Variables in parentheses are baseline measures for dummy coded variables. Positive coefficients imply positive influence on team coordination. Negative coefficients imply negative influence on team coordination.

\section{Discussion}

Our study lends strong support to the emerging concept of a team listening environment. We believe this is the first study to use the TLE scale and demonstrate this strong relationship with team coordination. To illustrate the strength of this relationship, Figure 1 provides a cross-tab of excellent (top third), average (middle third), and poor (bottom third) scores in terms of team coordination and team listening environment. Roughly 56 percent of professionals who were in an excellent team listening environment also stated that they were in a high team coordination environment. By contrast, just 8 percent of professionals who were in an excellent team listening environment also stated they were in a poor team coordination environment. We view these results as compelling evidence of the relationship between team listening environment and team coordination.

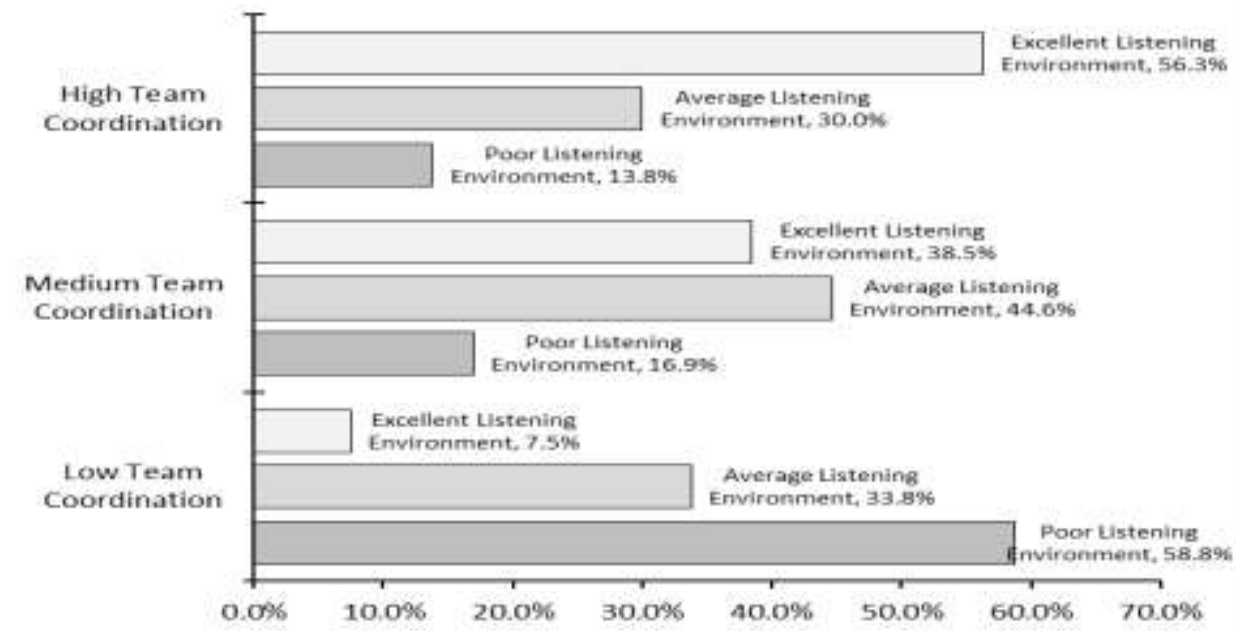

Figure 1. Team Coordination and Listening Environment.

We were also intrigued that employment tenure had not relationship with team coordination. We assumed that the longer employees had worked at an organization, the more likely they would have developed more efficient and effective working relationships with team members and, as a result, coordinate their team activities better. We also assumed that communication frequency would contribute to higher team coordination, as it had done some prior studies. Surprisingly, only one type of communication frequency - unscheduled meetings - contributed to higher team coordination. These findings seem to indicate that the frequency of scheduled meetings, email, and phone calls is insufficient to drive better team coordination. Rather, it is the team listening environment that is critical. This affirms that a quality approach to team communication is more critical than a quantity approach. 
Regarding the impact of unscheduled meetings, we think this finding is particularly noteworthy. It is the first known study to empirically and directly show the importance of unscheduled meetings on team coordination, confirming the implied advice of roughly five decades of management advice. It seems to indicate that, all else equal, meeting spontaneously more often helps teams manage their roles and responsibilities more effectively. It may also reflect the relative comfort and trust that team members have in one another. The increased frequency of unscheduled meetings implies that team members often depend on one another in their shared projects and that they feel comfortable approaching one another.

The two major findings from this study (that team listening orientation and the frequency of unscheduled meetings are drivers of team coordination) imply that business communication researchers may need to shift their paradigms towards less controlled and more spontaneous communications. One of the leading scholars of business communication, Judi Brownell, has actively endorsed a listening-centric view of business communication on primarily an interpersonal level (Brownell, 1990, 1992, 1994, 2010). Given the strong results of this study, we similarly recommend a listening-centric, more spontaneous view of teamwork and collaboration. In particular, we recommend scholars and trainers focus on the impacts of and steps to developing positive team listening environments. We recommend that this approach view a team listening environment as related to but distinct from listening competences in interpersonal interactions.

As far as training programs, we recommend that instructors and trainers consider how to help business professional gain competencies directly tied to the aspects of a positive team learning environment. In the interpersonal context, a variety of models of active listening have been developed to help business professional gain listening competencies. On the other hand, training models have not yet been developed specifically tied to the key aspects of a positive team listening environment. We encourage instructors and trainers to develop these training programs based on the components of the TLE scale and programs that allow entire teams to train together.

\section{Limitations and Future Research}

We think additional research about team listening environment should be conducted to replicate the results of this study, address the limitations of this study, and extend the results of this study. One limitation of this study is that it is based on self-perceptions. We encourage future studies to include external measures of team coordination and team performance. This study is also limited to a single moment in time for team members. We recommend research that examines the ebb and flow of team listening environment and frequency of communications over time. For example, a fruitful line of research might be how team listening and team communication vary during critical decision-making points during the course of a project.

Another limitation, and one which presents tremendous opportunity for future research, is the lack of richness and depth in a survey-based approach to this issue. Ethnographic approaches to examining team listening environment and the nature of unscheduled meetings in teams could yield better explanations and models of the nature of team listening and unscheduled meetings. Specifically, we recommend qualitative approaches to identify characteristics and obstacles to team listening. Also, we encourage researchers to qualitatively identify characteristics of spontaneous, unscheduled meetings and other communications within teams.

\section{Summary}

This study showed that the primary drivers of team coordination were a positive team listening environment and a higher frequency of unscheduled, spontaneous meetings. One major implication of these findings for business communication research, training, and practice is the need to focus on less tightly controlled and more spontaneous approaches to team communication. Since nearly all business communication research and curriculum focuses on controlled, agenda-driven approaches to team meetings and communication, business communication scholars who develop research and knowledge about spontaneous team communication may significantly advance the field.

\section{References}

Adler, P., Heckscher, C., \& Prusak, L. (2011, July-August). Building a collaborative enterprise. Harvard Business Review, 94-101.

Ames, D., Maissen, L. B., \& Brockner, J. (2012). The role of listening in interpersonal influence. Journal of Research in Personality, 46(3), 345-349. http://dx.doi.org/10.1016/j.jrp.2012.01.010

Arora, A., Gonzalez, V. M., \& Payne, S. J. (2011). The social nature of work fragmentation: Revisiting informal workplace communication. Ergonomics Open Journal, 4, 23-27.

http://dx.doi.org/10.2174/1875934301104010023

Baker, W. H. (1980). Defensiveness in communication: Its causes, effects, and cures. Journal of Business Communication, 17(3), 33-43. http://dx.doi.org/10.1177/002194368001700304 
Baltes, B. B., Dickson, M. W., Sherman, M. P., Bauer, C. C., \& LaGanke, J. S. (2002). Computer-mediated communication and group decision making: A meta-analysis. Organizational Behavior and Human Decision Processes, 87(1), 156-179. http://dx.doi.org/10.1006/obhd.2001.2961

Barker, R. T., Pearce, C. G., \& Johnson, I. W. (1992). An investigation of perceived managerial listening ability. Journal of Business and Technical Communication, 6(4), 438-457. http://dx.doi.org/10.1177/1050651992006004003

Beck, C. E., \& Beck, E. A. (1986, January-February). The manager's open door and the communication climate. Business Horizons, 15-19. http://dx.doi.org/10.1016/0007-6813(86)90080-7

Behn, R. D. (1988). Management by groping along. Journal of Policy Analysis and Management, 7(4), $643-663$. http://dx.doi.org/10.2307/3323485

Berry, G. R. (2006). Can computer-mediated asynchronous communication improve team processes and decision making? Learning from the management literature. Journal of Business Communication, 43(4), $344-366$. http://dx.doi.org/10.1177/0021943606292352

Berry, G. R. (2011). Enhancing effectiveness on virtual teams: Understanding why traditional team skills are insufficient. Journal of Business Communication, 48(2), 186-206. http://dx.doi.org/10.1177/0021943610397270

Brownell, J. (1990). Perceptions of effective listeners: A management study. Journal of Business Communication, 27(4), 401-415. http://dx.doi.org/10.1177/002194369002700405

Brownell, J. (1994). Managerial listening and career development in the hospitality industry. Journal of International Listening Association, 8, 31-49. http://dx.doi.org/10.1080/10904018.1994.10499130

Brownell, J. (1994). Teaching listening: Some thoughts on the behavioral approach. Business Communication Quarterly, 57(4), 19-26. http://dx.doi.org/10.1177/108056999405700404

Brownell, J. (2010). The skills of listening-centered communication. In A. D. Wolvin (Ed), Listening and human communication in the $21^{\text {st }}$ century (141-156). Malden, MA: John Wiley \& Sons.

Brunner, B. R. (2008). Listening, communication \& trust: Practitioners' perspectives of business/organizational relationships. International Journal of Listening, 22, 73-82. http://dx.doi.org/10.1080/10904010701808482

Burley-Allen, M. (2001). Listen up! HR Magazine, 46, 115-119.

Comer, L. B., \& Drollinger, T. (1999). Active empathetic listening and selling success: A conceptual framework. Journal of Personal Selling and Sales Management, 19(1), 15-29.

Cooper, L. O. (1997). Listening competency in the workplace: A model for training. Business Communication Quarterly, 60(4), 75-84. http://dx.doi.org/10.1177/108056999706000405

Cooper, L. O., \& Buchanan, T. (2003). Taking aim at good targets: Inter-rater agreement of listening competency. International Journal of Listening, 17, 88-114. http://dx.doi.org/10.1080/10904018.2003.10499057

Costa, A. C. (2003). Work team trust and effectiveness. Personnel Review, 32(5), 605-622. http://dx.doi.org/10.1108/00483480310488360

Costa, A. C., Roe, R. A., \& Taillieu, T. (2001). Trust within teams: The relation with performance effectiveness. European Journal of Work and Organizational Psychology, 10(3), 225-244. http://dx.doi.org/10.1080/13594320143000654

Costa, A. C., \& Anderson, N. (2011). Measuring trust in teams: Development and validation of a multifaceted measure of formative and reflective indicators of team trust. European Journal of Work and Organizational Psychology, 20(1), 119-154. http://dx.doi.org/10.1080/13594320903272083

Costa, A. C., \& Peiró, J. M. (2009). Trust and social capital in teams and organizations - antecedents, dynamics, benefits and limitations. Social Science Information, 48, 131-142. http://dx.doi.org/10.1177/0539018409102402

Daft, R. L., \& Lengel, R. H. (1986). Organizational information requirements, media richness and structural design. Management Science, 32(5), 554-571. http://dx.doi.org/10.1287/mnsc.32.5.554

Douglas, C., Martin, J. S., \& Krapels, R. H. (2006). Communication in the transition to self-directed teams. Journal of Business Communication, 43(4), 295-321. http://dx.doi.org/10.1177/0021943606291704

Dyer, W. G., Jr., Dyer, J. H., \& Dyer, W. G. (2013). Team building: Proven strategies for improving team performance ( $5^{\text {th }}$ ed.). San Francisco, CA: John Wiley \& Sons.

Flynn, J., Valikoski, T.-R., \& Grau, J. (2008). Listening in the business context: Reviewing the state of research. 
International Journal of Listening, 22, 141-151. http://dx.doi.org/10.1080/10904010802174800

Fussell, S. R., Kraut, R. E., Lerch, F. J., Scherlis, W. L., McNally, M. M., \& Cadiz, J. J. (1998). Coordination, overload and team performance. CSCW '98 Proceedings of the 1998 ACM conference on computer supported cooperative work, 275-284. http://dx.doi.org/10.1145/289444.289502

Gibb, J. R. (1961). Defensive communication. Journal of Communication, 9, 141-148. http://dx.doi.org/10.1111/j.1460-2466.1961.tb00344.x

GMAC. (2010). 2010 Alumni perspectives survey. McLean, VA: Graduate Management Admission Council, 2010.

Goby, V. P., \& Lewis, J. H. (2000). The key role of listening in business: A study of the Singapore insurance industry. Business Communication Quarterly, 63(2), 41-51. http://dx.doi.org/10.1177/108056990006300203

Gratton, L., \& Erickson, T. J. (2007, November). Eight ways to build collaborative teams. Harvard Business Review, 85(11), 100-110.

Haas, J. W., \& Arnold, C. L. (1995). An examination of the role of listening in judgments of communication competence in co-workers. Journal of Business Communication, 32(2), 123-139. http://dx.doi.org/10.1177/002194369503200202

Hambley, L. A., O’Neill, T. A., \& Kline, T. J. B. (2007). Virtual team leadership: The effects of leadership style and communication medium on team interaction styles and outcomes. Organizational Behavior and Human Decision Processes, 103(1), 1-20. http://dx.doi.org/10.1016/j.obhdp.2006.09.004

Handy, C. (1995, May). Trust and the virtual organization. Harvard Business Review, 73(5), 40-50.

Haythornthwaite, C. (2005). Social networks and Internet connectivity effects. Information, Communication \& Society, 8(2), 125-147. http://dx.doi.org/10.1080/13691180500146185

Haythornthwaite, C., Wellman, B., \& Mantei, M. (1994). Media use and work relationships in a research group. Proceedings of the Twenty-Seventh Annual Hawaii International Conference on System Sciences, 94-103. http://dx.doi.org/10.1109/HICSS.1994.323496

Ireland, R. D., Van Auken, P. M., \& Lewis, P. V. (1978). An investigation of the relationship between organization climate and communication climate. Journal of Business Communication, 16(1), 3-10. http://dx.doi.org/10.1177/002194367801600101

Jacobs, C., \& Coghlan, D. (2005). Sound from silence: On listening in organizational learning. Human Relations, 58(1), 115-138. http://dx.doi.org/10.1177/0018726705050938

Jarvenpaa, S. L., \& Leidner, D. E. (1999). Communication and trust in global virtual teams. Organizational Science, 10(6), 791-815. http://dx.doi.org/10.1287/orsc.10.6.791

Johnson, I. W., Pearce, C. G., Tuten, T. L., \& Sinclair, L. (2003). Self-imposed silence and perceived listening effectiveness. Business Communication Quarterly, 66(2), 23-38. http://dx.doi.org/10.1177/108056990306600203

Johnston, M. K., Reed, K., \& Lawrence, K. (2011). Team listening environment (TLE) scale. Journal of Business Communication, 48(1), 3-26. http://dx.doi.org/10.1177/0021943610385655

Katz, R. (1982). The effects of group longevity on project communication and performance. Administrative Science Quarterly, 27, 81-104. http://dx.doi.org/10.2307/2392547

Katz, R., \& Tushman, M. (1979). Communication patterns, project performance, and task characteristics: An empirical evaluation and integration in an R\&D setting. Organizational Behavior and Human Decision Processes, 23, 139-162. http://dx.doi.org/10.1016/0030-5073(79)90053-9

Kauffeld, S., \& Lehmann-Willenbrock, N. (2012). Meetings matter: Effects of team meetings on team and organizational success. Small Group Research, 43(2), 130-158. http://dx.doi.org/10.1177/1046496411429599

Kluger, A. V., \& Zaidel, K. (2013). Are listeners perceived as leaders? International Journal of Listening, 27(2), 73-84. http://dx.doi.org/10.1080/10904018.2013.754283

Kraut, R. E., Fish, R. S., Root, R. W., \& Chalfonte, B. L. (1990). Informal communication in organizations: Form, function, and technology. In Human reactions to technology: Claremont symposium on applied social psychology (pp. 145-199). Beverly Hills, CA: Sage Publications.

Kraut, R., Fussell, S., Lerch, E., \& Espinosa, A. (2005). Coordination in teams: Evidence from a simulated management 
game. Human-Computer Interaction Institute. Paper 102.

Lawler, E. E., \& Finegold, D. (2000). Individualizing the organization: Past, present, and future. Organizational Dynamics, 29, 1-15. http://dx.doi.org/10.1016/S0090-2616(00)00009-7

Leonardi, P. M., Neeley, T. B., \& Gerber, E. M. (2012). How managers use multiple media: Discrepant events, power, and timing in redundant communication. Organization Science, 23(1), 98-117. http://dx.doi.org/10.1287/orsc.1110.0638

MacLeod, L., Scriven, J., \& Wayne, F. S. (1992). Gender and management level differences in the oral communication patterns of bank managers. Journal of Business Communication, 29, 343-365. http://dx.doi.org/10.1177/002194369202900403

Maltz, E. (2003). Is all communication created equal?: An investigation into the effects of communication mode on perceived information quality. Journal of Product Innovation Management, 17(2), 110-127. http://dx.doi.org/10.1016/S0737-6782(99)00030-2

Marks, M. A., Mathieu, J. E., \& Zaccaro, S. J. 2001. A temporally based framework and taxonomy of team processes. Academy of Management Review, 26(3), 356-376.

Martinko, M. J., \& Gardner, W. L. (1990). Structured observation of managerial work: A replication and synthesis. Journal of Management Studies, 27(3), 329-357. http://dx.doi.org/10.1111/j.1467-6486.1990.tb00250.x

Mathieu, J., Maynard, M. T., Rapp, T., \& Gilson, L. (2008). Team effectiveness 1997-2007: A review of recent advancements and a glimpse into the future. Journal of Management, 34(3), 410-476. http://dx.doi.org/10.1177/0149206308316061

McDonough, E. F. (1999). Managing communication in global product development teams. IEEE Transactions on Engineering Management, 46(4), 375-386. http://dx.doi.org/10.1109/17.797960

Mickelson, W. T., \& Welch, S. A. (2013). Improving the performance of the listening competency scale: Revision and validation. International Journal of Listening, 27(3), 157-171. http://dx.doi.org/10.1080/10904018.2013.821355

Mineyama, S., Tsutsumi, A., Takao, S., Nishiuchi, K., \& Kawakami, N. (2007). Supervisors' attitudes and skills for active listening with regard to working conditions and psychological stress reactions among subordinate workers. Journal of Occupational Health, 49(2), 81-87. http://dx.doi.org/10.1539/joh.49.81

Mintzberg, H. (1971). Managerial work: Analysis from observation. Management Science, 18(2), 97-110. http://dx.doi.org/10.1287/mnsc.18.2.B97

Oshagbemi, T. (1995). Management development and managers' use of their time. Journal of Management Development. Journal of Management Development, 14(8), 19-34. http://dx.doi.org/10.1108/02621719510097398

Panko, R. R. (1992). Managerial communication patterns. Journal of Organizational Computing, 2(1), 95-122. http://dx.doi.org/10.1080/10919399209540176

Pearce, C. G., Johnson, I. W., \& Barker, R. T. (2003). Assessment of the listening styles inventory: Progress in establishing reliability and validity. Journal of Business and Technical Communication, 17(1), 84-113. http://dx.doi.org/10.1177/1050651902238546

Peters, T., \& Waterman, R. H. (1982). In search of excellence. New York: Harper \& Row.

Ramsey, R. P., \& Sohi, R. S. (1997). Listening to your customers: The impact of perceived salesperson listening behavior on relationship outcomes. Journal of the Academy of Marketing Science, 25(2), 127-137. http://dx.doi.org/10.1007/BF02894348

Rogelberg, S. G., Leach, D. J., Warr, P. B., \& Burnfield, J. L. (2006). "Not another meeting!” Are meeting demands related to employee well-being? Journal of Applied Psychology, 91(1), 86-96. http://dx.doi.org/10.1037/0021-9010.91.1.83

Staples, S., \& Webster. J. (2003). A review and classification of research on virtual teams and an identification of research opportunities. Paper presented at the meeting of the Society for Industrial and Organizational Psychology, Orlando, Florida.

Stine, M., Thompson, T., \& Cusella, L. (1995). The impact of organizational structure and supervisory listening indicators on subordinate support, trust, intrinsic motivation, and performance. International Journal of Listening, 9(1), 84-105. http://dx.doi.org/10.1080/10904018.1995.10499143 
Taylor, J., \& Bowers, D. (1972). The survey of organizations: A machine-scored standardized questionnaire instrument. Ann Arbor, MI: Institute for Social Research.

Tesluk, P., \& Mathieu, J. E. (1999). Overcoming roadblocks to effectiveness: Incorporating management of performance barriers into models of work group effectiveness. Journal of Applied Psychology, 84, $200-217$. http://dx.doi.org/10.1037/0021-9010.84.2.200

Watson, K. W., Barker, L. L., \& Weaver, J. M. (1995). The listening styles profile (LPP16): Development and validation of an instrument to assess four listening styles. International Journal of Listening, 9, 1-13. http://dx.doi.org/10.1080/10904018.1995.10499138

Webster, J., \& Hackley, P. (1997). Teaching effectiveness in technology-mediate distance learning. Academy of Management Journal, 40, 1282-1309. http://dx.doi.org/10.2307/257034

(cc) $\mathrm{BY}$

This work is licensed under a Creative Commons Attribution 3.0 License. 